\title{
Impact of Gold Mining on Soil and some Staple Foods Collected from Selected Mining Communities in and around Tarkwa- Prestea Area
}

\author{
E. K Hayford ${ }^{1}$, A. Amin², E. K. Osae ${ }^{3}$ and J. Kutu ${ }^{1}$ \\ ${ }^{1}$ Department of Geology, University of Ghana, Legon, Accra \\ ${ }^{2}$ Department of Environmental Science, University of Ghana, Legon, Accra \\ ${ }^{3}$ Department of Physics, University of Ghana, Legon, Accra
}

\begin{abstract}
The principle of neutron activation was used to investigate the presence of toxic elements and possible heavy metals in samples of cassava, plantain and soil from the mining communities in and around Tarkwa in the Western Region of Ghana. The results showed that the maximum concentrations of the respective metals in cassava: plantain: soil samples were arsenic (As $=0.7 \mu \mathrm{g} / \mathrm{g}: 0.25 \mu \mathrm{g} / \mathrm{g}: 14.35 \mu \mathrm{g} / \mathrm{g}$ ), mercury $(\mathrm{Hg}=0.25 \mu \mathrm{g} / \mathrm{g}: 0.52 \mu \mathrm{g} / \mathrm{g}: 0.09 \mu \mathrm{g} / \mathrm{g}$ ), antimony ( $\mathrm{Sb}=0.03$ $\mu \mathrm{g} / \mathrm{g}: 0.03 \mu \mathrm{g} / \mathrm{g}: 2.98 \mu \mathrm{g} / \mathrm{g}$ ), chromium ( $\mathrm{Cr}=0.72 \mu \mathrm{g} / \mathrm{g}: 3.42 \mu \mathrm{g} / \mathrm{g}: 40.35 \mu \mathrm{g} / \mathrm{g}$ ), vanadium (V = 0.8 $\mu \mathrm{g} / \mathrm{g}: 0.76 \mu \mathrm{g} / \mathrm{g}: 188.40$ $\mu \mathrm{g} / \mathrm{g}$ ), zinc ( $\mathrm{Zn}=38.42 \mu \mathrm{g} / \mathrm{g}: 24.92 \mu \mathrm{g} / \mathrm{g}: 42.36 \mu \mathrm{g} / \mathrm{g})$, and copper $(\mathrm{Cu}=66.39 \mu \mathrm{g} / \mathrm{g}: 8.74 \mu \mathrm{g} / \mathrm{g}: 53.46 \mu \mathrm{g} / \mathrm{g})$. The concentrations in cassava and plantain were higher than the values proposed by the FAO, the Expert Committee on Food Additives of the WHO and the Agency for Toxic Substance and Disease Registry (ATSDR). The concentrations of Hg $(0,09 \mu \mathrm{g} / \mathrm{g})$ in soil at Teberebie and of V (188.40ìg/g) at the University of Mines and Technology (UMaT) in soil were above the permitted concentrations of $5 \mu \mathrm{g} / \mathrm{g}$ and $90 \mu \mathrm{g} / \mathrm{g}$, respectively. Samples from communities further away from the centres of mine drainages (mile 81/2, mile 101/2) had smaller values of element concentrations. An enrichment factor (EF) analysis for both cassava and plantain were $\mathrm{Zn} \mathrm{(7 \% )} \mathrm{and} \mathrm{Hg}$ (90\%). The remaining elements together add up to $3 \%$. The enrichment factor analysis for plantain is greater than that for cassava. Mercury is the element that is chiefly enriched in both cassava and plantain. The second predominant element enriched in cassava and plantain is zinc.
\end{abstract}

\section{Introduction}

Mining is the process of extracting minerals from the earth. The history of small scale gold mining in Ghana dates as far back as the 4th century, when indigenous craftsmen made use of gold in diverse ways. The search for gold took a higher dimension in 1471, when the Europeans arrived and the silent trade began. Commercial scale gold mining, however, is believed to have commenced in Ghana during the 19th century by the British (Tsikata, 1997).

Mining in Ghana currently includes the extraction of gold, bauxite, manganese and diamond in commercial quantities. Among these, gold mining is the most prominent and contributed to 93\% of the exports made in 2004 (Minerals Commission, Ghana, 2004). Ghana is one of the major gold producing countries; ranking 10th in the world and second in Africa. The mining sector currently (2008) contributes about 7\% of Ghana's total corporate tax earnings. It forms $41 \%$ of total export, $12 \%$ of Government revenue collected by the Internal Revenue Service and 5\% of the total GDP.

Export revenue from the sector for 2007 totaled US $\$ 2.5$ billion. The sector directly employs over 20,000 people in the large scale mining sector, while over 500,000 people are known to be engaged in the small scale gold, diamond, sand winning and quarry operations (Mineral Commission, Ghana). Although Anglo Gold-Obuasi and Newmont, two of the major producers of gold in Ghana are in the Ashanti Region, the largest concentration of mining companies are, however, found in the Tarkwa-Wassaw District. Within this District are Tarkwa Goldmines, Aboso Goldmines, Teberebie Goldmines, Bogoso Goldmines, Bonte Goldmines and small scale artisanal gold mining (AGM) operators, who legally or illegally mine the gold using toxic chemicals.

In AGM, gold is extracted mainly from alluvial deposits along rivers, waterways and terrestrial soils. Gold is then processed by crushing and grinding of the gold-bearing ore. The gold is then extracted from the concentrate by adding mercury to form gold-amalgam which is then roasted in open air to obtain the metal gold. The mercury so exposed to atmospheric, aquatic and terrestrial 
influences undergoes series of transformation, eventually becoming methyl-mercury which is a neurotoxin, and the most toxic form of the metal (Cleary \& Thornton, 1994).

The large and small scale mining processes impact negatively on the environment and the socioeconomic status of the communities in which they operate (Encarta, 2002). The processing of the ore body and its waste product disposal method are considered a major source of environmental pollution. Typical of most mining operations are tailings that consist of crushed ore and rock bodies after most of the needed metals have been removed. Mine tailings are often toxic and pose serious threats to human, animal and plant life.

Despite the potential threats, these tailings are retained in sedimentation ponds and piled up for future treatment, while the slime goes with the overflow into nearby streams. This practice normally leads to siltation of nearby streams, destroying aquatic fauna and flora. Where the sedimentation ponds contain sulphides (pyrites, arsenopyrites, etc.), which is often the case, there is oxidation of the sulphides in the tailings, leading to the lowering of the $p \mathrm{H}$ in the effluent waters. From the acidic effluent water in the sedimentation ponds begins the leaching of elements such as mercury, arsenic, zinc, copper, vanadium, antimony and chromium. The effluent subsequently ends up in nearby streams and rivers, introducing its dissolved toxic elements into them. The result is increases in health problems, like severe intestinal upsets, keratosis and skin cancer (Steinnes \& Berg, 1998) in blood samples from some of the communities that have already been investigated.

Previous studies on $\mathrm{Hg}$ pollution in Ghana deals with research data on some of the rivers draining south-western Ghana. Adimado \& Baah (2002) studied Hg concentrations in human blood, urine, and fish from Ankobra and Tano rivers. Bannerman et al. (2003) reported $\mathrm{Hg}$ and As contaminations in sediments and water in gold mining regions in the Ankobra river basin. Similarly, Bonzongo et al. (2003) investigated water, soil and sediments from artisanal gold mining areas, and reported high $\mathrm{Hg}$ and toxic element concentrations. Brief studies have also been carried out on toxic minerals in sediments and soils of the Offin river with similar results.

Indeed the effects of these toxic elements like mercury and arsenic on staple foods such as cassava and plantain, as well as the soils in communities such as Bankyim, Akyempem, Teberebie, and UMaT in the Tarkwa Wassaw area are still unknown. The objective of this paper is to investigate and to determine the values of concentrations $(\mu \mathrm{g} / \mathrm{g})$ of the toxic elements in the samples collected from selected communities, to compare the values with international and local limits, and to assess the relative influences of the drainages from the gold mining industries on the values obtained.

\section{Study area}

\section{Materials and methods}

Tarkwa and its environs is part of the Western Region and lies between longitude $2^{\circ} 30^{\prime} \mathrm{W}$ and $1^{\circ}$ $45^{\prime} \mathrm{W}$ and latitude $4^{\circ} 50^{\prime} \mathrm{N}$ and $5^{\circ} 45^{\prime} \mathrm{N}$. It is part of the Wassaw District. Tarkwa is the capital of this District and lies $60 \mathrm{~km}$ northeast of Axim, $50 \mathrm{~km}$ northwest of Takoradi and $150 \mathrm{~km}$ south of Kumasi. The District has a total area of $2354 \mathrm{~km}^{2}$. The topography shows plateaus with heights between 600 and $1050 \mathrm{~m}$. The flat areas towards the south of Tarkwa are being used for agriculture. Large plantations of orange, rubber and palm are found in this area.

The border line between the tropical rain forest in the Ashanti Region and the tropical vegetation of the coastal region runs through Tarkwa and its environs. The average rainfall is $850 \mathrm{~mm}$ per year, and is mostly recorded between June and October. Planting and harvesting are mostly done during this period. Traditional foodstuffs planted in this area are cassava, plantain, yam, cocoyam, oranges and vegetables. 
Scattered randomly between these farmlands are six major mining companies and several small scale artisenal mining groups. In and around this area are several streams and rivers. Among them are the Ankobra river, Monsi river, the Pra river, the Offin river and the Tano river. The communities, farms, the mining companies and the river system are related and interdependent, sharing common boundaries. It is from this system that cassava, plantain and soil samples from seven selected communities were collected. These com-munities are Bankyim, Tamso, Acheampong Village, Oseikrom, Domeabra, Nkwantakrom and Teberebie.

\section{Geology of south-western Ghana}

The geology of southwestern Ghana is made up of the Birimian supergroup (rich in mineralized quartz veins and sulphides) and the Tarkwa series (rich in mineralized conglomerates). One of the most striking features of the geology of southwestern Ghana is the existence of five parallel and evenly spaced volcanic belts and the sedimentary basins forming the Birimian supergroup. The SW-NE directed volcanic belts, rich in economic gold, are the Kibi Winneba belt, Ashanti belt (Fig. 1) Sefwi belt, the Bui belt, and the Bole-Navrongo belt. Within the Ashanti belt are found all the gold producing towns and mining companies in the Tarkwa-Wassaw District. Data from gravity survey by Hastings (1983) indicate that the volcanic belts lie for considerable distance below the young cover of Voltaian sediments which is found northeast of Ghana. Their widths lie generally between 15-40 cm (Hirdes \& Leube, 1986).

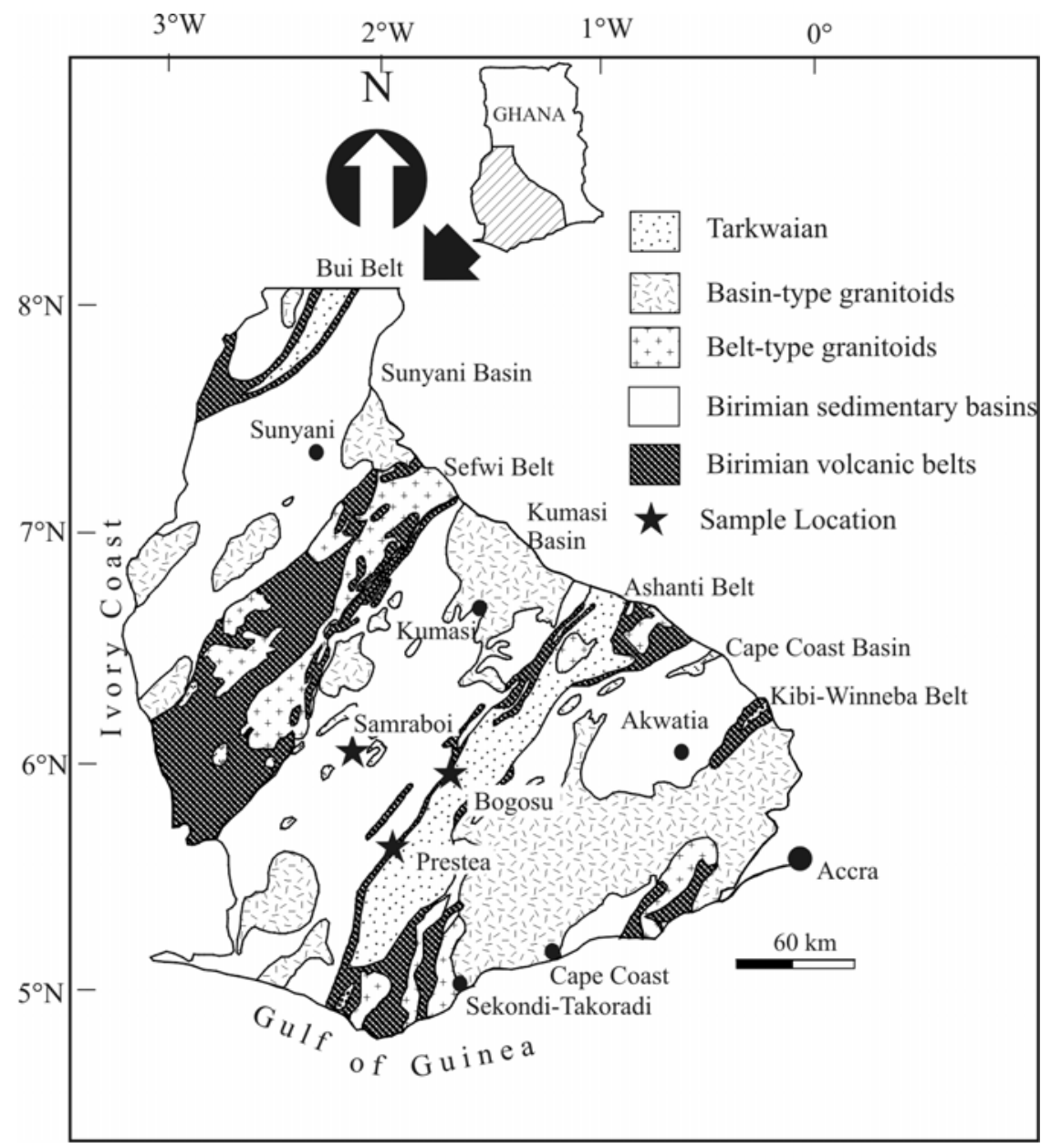

Fig. 1. Geological map of southern Ghana showing sample locations in the Birimian supergroup and the basin type granitoid. Samples were taken from sample locations at Prestea, Bogoso and Samraboi (modified after Taylor \& McLennan, 1992) 
The terrains between the individual belts consists of isoclinally folded metasedi-mentary rocks and granitoids in varying proportions. High ratios of granitoid and metasediments are observed particularly in the south-west of the Kibi-Winneba belt. These exposures are possibly due to intensities in erosion.

\section{Materials and methods}

Samples of cassava, plantain and soil were collected from farmlands in seven mining communities. A total of 25 plantain samples, 25 cassava samples and 25 soil samples were collected. The samples were collected in May and June at the beginning of the rainy season. Samples were collected from farms close to communities. More samples were collected further away from the com-munities. Farms very close to the mining companies were not sampled to avoid data which might not be representative. All the samples were stored in dried polythene bags and transported to the Ghana Research Reactor-1 (GHARR-1) premises for further analysis.

\section{Theoretical background}

Mining can take two forms, surface and underground mining. Underground mines are large tunnels that are dug deep into the ground to reach minerals that cannot be reached from the surface. Such deep tunnels, sometimes about $2 \mathrm{~km}$ deep, may be a source of pollution to the ground water. Such polluted ground water often undergo ionic exchange with the rocks in the immediate surroundings of the ground water. It might also affect water from bore holes drilled in the immediate vicinity. However, such polluted water has very little or no effect on cassava, plantain and soil samples on the surface. Pollution of these samples occur where surface mining lead to surface drainage processes.

Surface drainage processes and mine water disposal, with its related oxidation, lead to the phenomena known as acid rock drainage (ARD). The ARD is leached into rocks and soils which then drains into rivers, streams and lakes, most of which are sources of drinking water for the communities. The source of the contamina-tion are two major forms of iron-disulphide, that is pyrite and marcasite. Because of its orthorhombic structure, marcasite is less stable than pyrite. According to Berner (1970), the formation of pyrite is in three steps: (i) reduction of sulphate to sulphide by bacteria, (ii) reaction of the hydrogen sulphide with iron minerals to form monosulphides, and (iii) reaction of the iron monosulphides with elemental sulphur to form pyrite. Where organic matter content is high pyrite is believed to form rapidly (Giblin, 1988). Pyrite is also associated with many ores including zinc, copper, uranium, gold and silver, among others. Thus, it is the belief of many geochemists that pyrite is the major contributor to the degradation of water quality and, in general, the cause of environmental pollution during the process of mining.

The reaction of pyrite $\left(\mathrm{FeS}_{2}\right)$ upon exposure to air and water are as follows:

$$
\begin{aligned}
& \mathrm{Fe} \mathrm{S}_{2}+7 / 2 \mathrm{O}_{2}+\mathrm{H}_{2} \mathrm{O}=\mathrm{Fe}^{\mathrm{II}}+2 \mathrm{SO}_{4}{ }^{2}+2 \mathrm{H}^{+} \ldots \ldots \ldots \ldots . . . \\
& \mathrm{Fe}^{\mathrm{II}}+1 / 4 \mathrm{O}_{2}+\mathrm{H}^{+}=\mathrm{Fe}^{\mathrm{III}}+1 / 2 \mathrm{H}_{2} \mathrm{O} \ldots \ldots . .(2) \\
& \mathrm{Fe}^{\mathrm{III}}+3 \mathrm{H}_{2} \mathrm{O}=\mathrm{Fe}(\mathrm{OH})_{3}+3 \mathrm{H}^{+} \ldots \ldots . . .(3) \\
& \mathrm{FeS}_{2}+14 \mathrm{Fe}^{\mathrm{III}}+8 \mathrm{H}_{2} \mathrm{O}=15 \mathrm{Fe}^{\mathrm{II}}+2 \mathrm{SO}_{4}^{2-}+16 \mathrm{H}^{+}
\end{aligned}
$$

Reaction (1) shows oxidation of the sulphide, thus, releasing ferrous iron ( $\mathrm{Fe}^{\mathrm{II}}$ ) and two protons. In reaction (2) the ferrous iron is oxidized to ferric ( $\mathrm{Fe}^{\mathrm{III}}$ ) which eventually hydrolyzes to form ferric hydroxide, an insoluble compound at a $p \mathrm{H}$ greater than 5.3. From the above reactions it is clear that pyrite continues to oxidize as long as ferric iron is generated.

With the release of protons on exposure to air and water, the tailings that are left behind after the mineral processing weather and leach out harmful elements such as $\mathrm{Hg}, \mathrm{As}, \mathrm{Cd}, \mathrm{Ur}, \mathrm{Zn}, \mathrm{V}, \mathrm{Cu}, \mathrm{Ch}$, among others, to contaminate surface water. This contamina-tion directly or indirectly affect the soil and foodstuffs. Using the principle of neutron activation it is possible after irradiation for the detector of the research reactor to calculate the concentrations of the elements. 
The soil samples were collected at a depth between 10-20 cm using the hand auger and plastic trowel. The soil samples were air-dried below $25^{\circ} \mathrm{C}$ for 5 days. The samples were then ground and sieved using a $180-\mu \mathrm{m}$ mesh size to obtain fine grains. Six replicate samples, $100 \mathrm{mg}$ each of the soil samples were weighed into clean polyethylene foils, wrapped and heat-sealed. The subsamples, were placed in about $15 \mathrm{ml}$ volume polyethylene capsules and heat-sealed.

The cassava and plantain samples were peeled and the edible parts were washed with deionized distilled water, put into petry dishes and labeled. The samples were then dried in a Gallenkamp oven at $40{ }^{\circ} \mathrm{C}$ for $24 \mathrm{~h}$. Later, the food samples were ground into powder using agate mortar and homogenized using a Waring Commercial Blender, MPR-100-015S. Six replicate samples, $200 \mathrm{mg}$ each of the food samples, were weighed into clean polyethylene foils, wrapped and heat-sealed. The sub-samples were placed in about $15 \mathrm{ml}$ volume polyethylene capsules and heat-sealed.

The samples were irradiated using a $30 \mathrm{~kW}$ tank-in-pool Ghana Research Reactor-1 (GHARR-1) facility operating at a thermal neutron flux of $5 \times 10^{11} \mathrm{~ns}^{-1} \mathrm{~cm}^{-2}$. Counting was done using a PCbased gamma ray spectroscopy system consisting of high purity Germanium detector operating at a bias voltage of $3000 \mathrm{~V}$. The spectral intensities of the elements of interest in the samples were accumulated by means of multi- channel analyzer (MCA). The accumulated spectral intensities were analyzed both quantitatively and qualitatively. The PC-based gamma-ray spectroscopy system was used for the measurement. The accumulated spectral intensities were analyzed both quantitatively and qualitatively. Samples from 21 localities were collected and analyzed. After the analysis, however, 10 localities, where maximum and minimum values were recorded, were selected for consideration and discussion.

\section{Results and discussion}

The results of concentrations ( $\mu \mathrm{g} / \mathrm{g}$ ) of cassava, plantain and soil obtained from the laboratory analysis indicate that the rate of As consumption in plantain and cassava (Tables 1 and 2) is higher than the $20 \mu \mathrm{g} /$ day limit approved by the Joint FAO/WHO Expert Committee on Food Additives (Fig. 2 and Fig. 3). Communities most affected are mile 5 and mile 7, Jerusalem, and Bankyemu.

TABLE 1

Toxic metal concentrations in cassava sample. Table also shows communities where maximum and minimum values were recorded. Nkwanta $=$ Nkwantakrom; Highway $Q=$ Highway Quarters

\begin{tabular}{|c|c|c|c|c|c|c|}
\hline \multicolumn{2}{|c|}{ Toxic elements } & \multicolumn{2}{|l|}{ Sample Ort } & \multirow{2}{*}{$\begin{array}{l}\text { Values } \\
0.7 \mu \mathrm{g} / \mathrm{g}\end{array}$} & \multirow{2}{*}{$\begin{array}{l}\text { Dosage/day } \\
560 \mu \mathrm{g} / \text { day }\end{array}$} & \multirow[t]{2}{*}{ FAO/WHO } \\
\hline As & $\max$ & Jerusalem & (B) & & & \\
\hline & $\min$ & Bankyim & (C) & $0.16 \mu \mathrm{g} / \mathrm{g}$ & 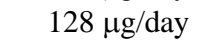 & $20 \mu \mathrm{g} /$ day \\
\hline \multirow[t]{2}{*}{$\mathrm{Hg}$} & $\max$ & Mile 7 & $(\mathrm{G})$ & $0.59 \mu \mathrm{g} / \mathrm{g}$ & $472 \mu \mathrm{g} /$ day & \\
\hline & $\min$ & Nkwanta & (O) & $0.22 \mu \mathrm{g} / \mathrm{g}$ & $176 \mu \mathrm{g} /$ day & $2.14 \mu \mathrm{g} / \mathrm{day}$ \\
\hline \multirow[t]{2}{*}{$\mathrm{Sb}$} & $\max$ & Agege & (M) & $0.03 \mu \mathrm{g} / \mathrm{g}$ & $24 \mu \mathrm{g} / \mathrm{day}$ & \\
\hline & $\min$ & Bankyim & (C) & $0.01 \mu \mathrm{g} / \mathrm{g}$ & $8 \mu \mathrm{g} /$ day & $5 \mu \mathrm{g} / \mathrm{day}$ \\
\hline \multirow[t]{2}{*}{$\mathrm{V}$} & $\max$ & Highway Q. & (S) & $0.8 \mu \mathrm{g} / \mathrm{g}$ & $640 \mu \mathrm{g} /$ day & \\
\hline & $\min$ & Akafo & (R) & $0.1 \mu \mathrm{g} / \mathrm{g}$ & $80 \mu \mathrm{g} /$ day & $10 \mu \mathrm{g} /$ day \\
\hline \multirow[t]{2}{*}{$\mathrm{Cu}$} & $\max$ & Mile 81/2 & (I) & $66.39 \mu \mathrm{g} / \mathrm{g}$ & $53,112 \mu \mathrm{g} /$ day & \\
\hline & $\min$ & Agege & $(\mathrm{M})$ & $0.82 \mu \mathrm{g} / \mathrm{g}$ & 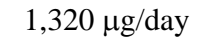 & $12 \mu \mathrm{g} /$ day \\
\hline \multirow[t]{2}{*}{$\mathrm{Zn}$} & $\max$ & Teberebie & (U) & $38.42 \mu \mathrm{g} / \mathrm{g}$ & 30,736 $\mu \mathrm{g} /$ day & \\
\hline & $\min$ & Domeabra & (P) & $14.82 \mu \mathrm{g} / \mathrm{g}$ & $11,856 \mu \mathrm{g} /$ day & $0.045 \mu \mathrm{g} /$ day \\
\hline \multirow[t]{2}{*}{$\mathrm{Cr}$} & $\max$ & Teberebie & (U) & $0.72 \mu \mathrm{g} / \mathrm{g}$ & $570 \mu \mathrm{g} /$ day & \\
\hline & $\min$ & Nkwanta & $(\mathrm{O})$ & $0.15 \mu \mathrm{g} / \mathrm{g}$ & 120 g/day & $25 \mu \mathrm{g} /$ day \\
\hline
\end{tabular}

TABLE 2

Toxic metal concentrations in plantain sample Table also shows communities where maximum and minimum values were recorded. Nkwanta $=$ Nkwantakrom; Highway $Q=$ Highway Quarters 


\begin{tabular}{|c|c|c|c|c|c|c|}
\hline \multicolumn{2}{|c|}{ Toxic elements } & \multicolumn{2}{|l|}{ Sample Ort } & \multirow{2}{*}{$\begin{array}{c}\text { Values } \\
0.53 \mu \mathrm{g} / \mathrm{g}\end{array}$} & \multirow{2}{*}{$\begin{array}{l}\text { Dosage/day } \\
424 \mu \mathrm{g} / \text { day }\end{array}$} & \multirow[t]{2}{*}{ FAO/WHO } \\
\hline As & $\max$ & Mile 5 & (F) & & & \\
\hline & $\min$ & Mile 7 & (G) & $0.14 \mu \mathrm{g} / \mathrm{g}$ & $112 \mu \mathrm{g} /$ day & $20 \mu \mathrm{g} /$ day \\
\hline \multirow[t]{2}{*}{$\mathrm{Hg}$} & $\max$ & Tamso & (D) & $0.52 \mu \mathrm{g} / \mathrm{g}$ & $416 \mu \mathrm{g} / \mathrm{day}$ & \\
\hline & $\min$ & Nkwanta. & (O) & $0.19 \mathrm{ug} / \mathrm{g}$ & $152 \mu \mathrm{g} /$ day & $2.14 \mu \mathrm{g} /$ day \\
\hline \multirow[t]{2}{*}{$\mathrm{Sb}$} & $\max$ & Agege & (M) & $0.03 \mu \mathrm{g} / \mathrm{g}$ & $24 \mu \mathrm{g} / \mathrm{day}$ & \\
\hline & $\min$ & Bankyim & (C) & $0.01 \mu \mathrm{g} / \mathrm{g}$ & $8 \mu \mathrm{g} / \mathrm{day}$ & $5 \mu \mathrm{g} / \mathrm{day}$ \\
\hline \multirow[t]{2}{*}{ V } & $\max$ & Highway Q. & $(S)$ & $0.76 \mu \mathrm{g} / \mathrm{g}$ & $608 \mu \mathrm{g} /$ day & \\
\hline & $\min$ & Akafo & (R ) & $0.08 \mu \mathrm{g} / \mathrm{g}$ & $64 \mu \mathrm{g} / \mathrm{day}$ & $10 \mu \mathrm{g} / \mathrm{day}$ \\
\hline \multirow[t]{2}{*}{$\mathrm{Cu}$} & $\max$ & Domeabra & $(\mathrm{P})$ & $8.74 \mu \mathrm{g} / \mathrm{g}$ & 6,992 $\mu \mathrm{g} /$ day & \\
\hline & $\min$ & Jerusalem & (B) & $2.13 \mu \mathrm{g} / \mathrm{g}$ & $1,704 \mu \mathrm{g} /$ day & $12 \mu \mathrm{g} /$ day \\
\hline \multirow[t]{2}{*}{ Zn } & $\max$ & Teberebie & (U) & $24.92 \mu \mathrm{g} / \mathrm{g}$ & $19936 \mu \mathrm{g} /$ day & \\
\hline & $\min$ & Domeabra & (P) & $12.82 \mu \mathrm{g} / \mathrm{g}$ & $10256 \mu \mathrm{g} /$ day & $0.045 \mu \mathrm{g} / \mathrm{day}$ \\
\hline \multirow[t]{2}{*}{$\mathrm{Cr}$} & $\max$ & Tamso & (D) & $3.42 \mu \mathrm{g} / \mathrm{g}$ & 2,736 $\mu \mathrm{g} /$ day & \\
\hline & $\min$ & Mile 8 & $(\mathrm{H})$ & $0.98 \mu \mathrm{g} / \mathrm{g}$ & $784 \mu \mathrm{g} /$ day & $25 \mu \mathrm{g} /$ day \\
\hline
\end{tabular}

Tables 1 and Table 2 further show that the amount of $\mathrm{Hg}$ absorbed in a day by a person who consumes plantain and cassava at Tamso and Nkwantakrom is higher than the estimated daily intake of $2.14 \mu \mathrm{g} /$ day of $\mathrm{Hg}$ permitted by the Joint FAO/WHO Expert Committee on Food Additives. In both Tamso and Nkwantakrom, the concentra-tions of As and Hg in soil (Table 3) fall within the permissible level. Only Teberebie recorded slightly higher concen-tration of $\mathrm{Hg}$ in soil (Fig. 4). At Agege Sb concentrations of $0.03 \mu \mathrm{g} / \mathrm{g}$ and $24 \mu \mathrm{g} / \mathrm{day}$ were recorded. The maximum intake of $5 \mu \mathrm{g} / \mathrm{day}$ is, however, the estimated amount stipulated by the Agency for Toxic Substance and Disease Registry. This shows an increase of $19 \mu \mathrm{g} / \mathrm{g}$ above the permitted level (Table 1).

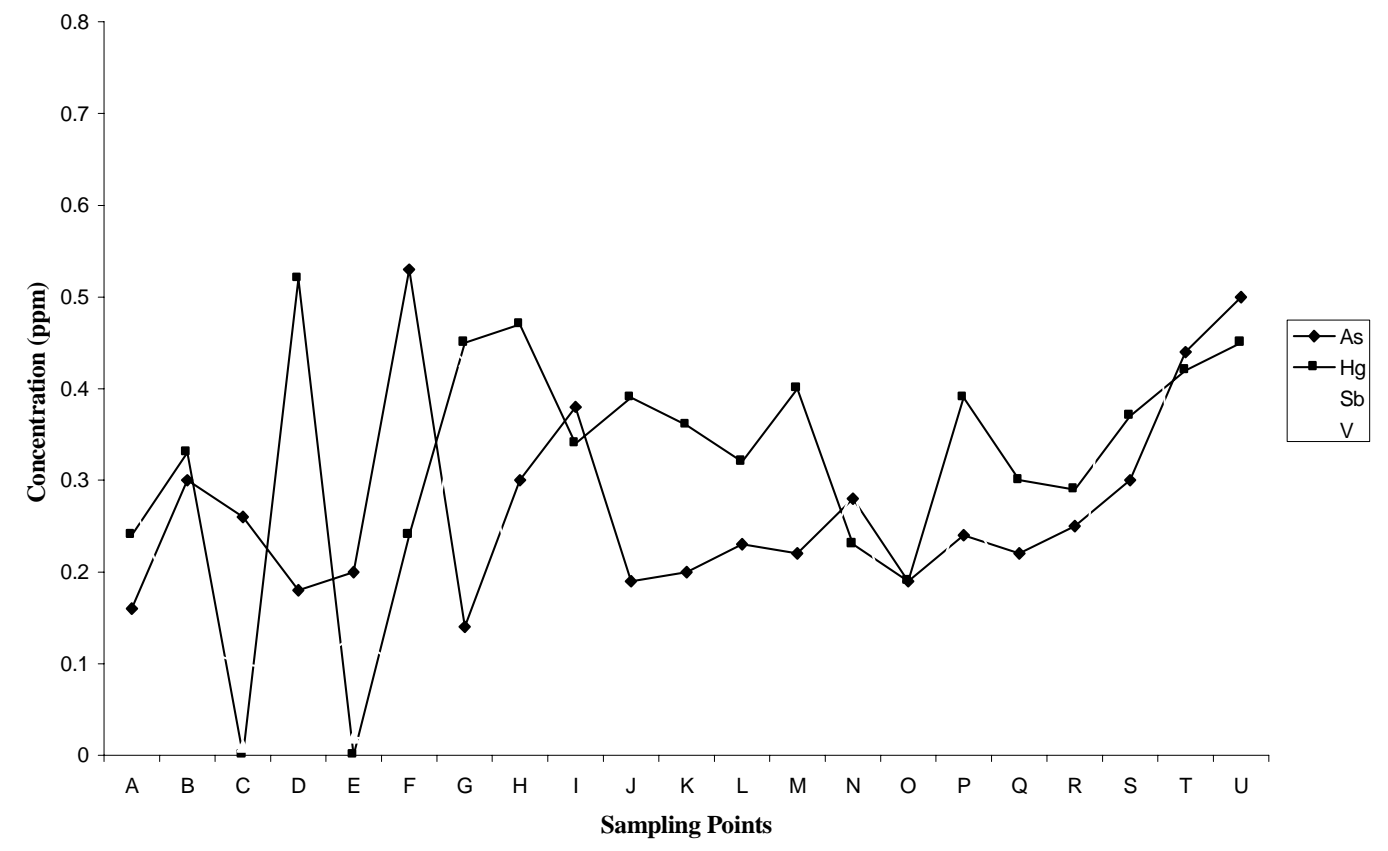




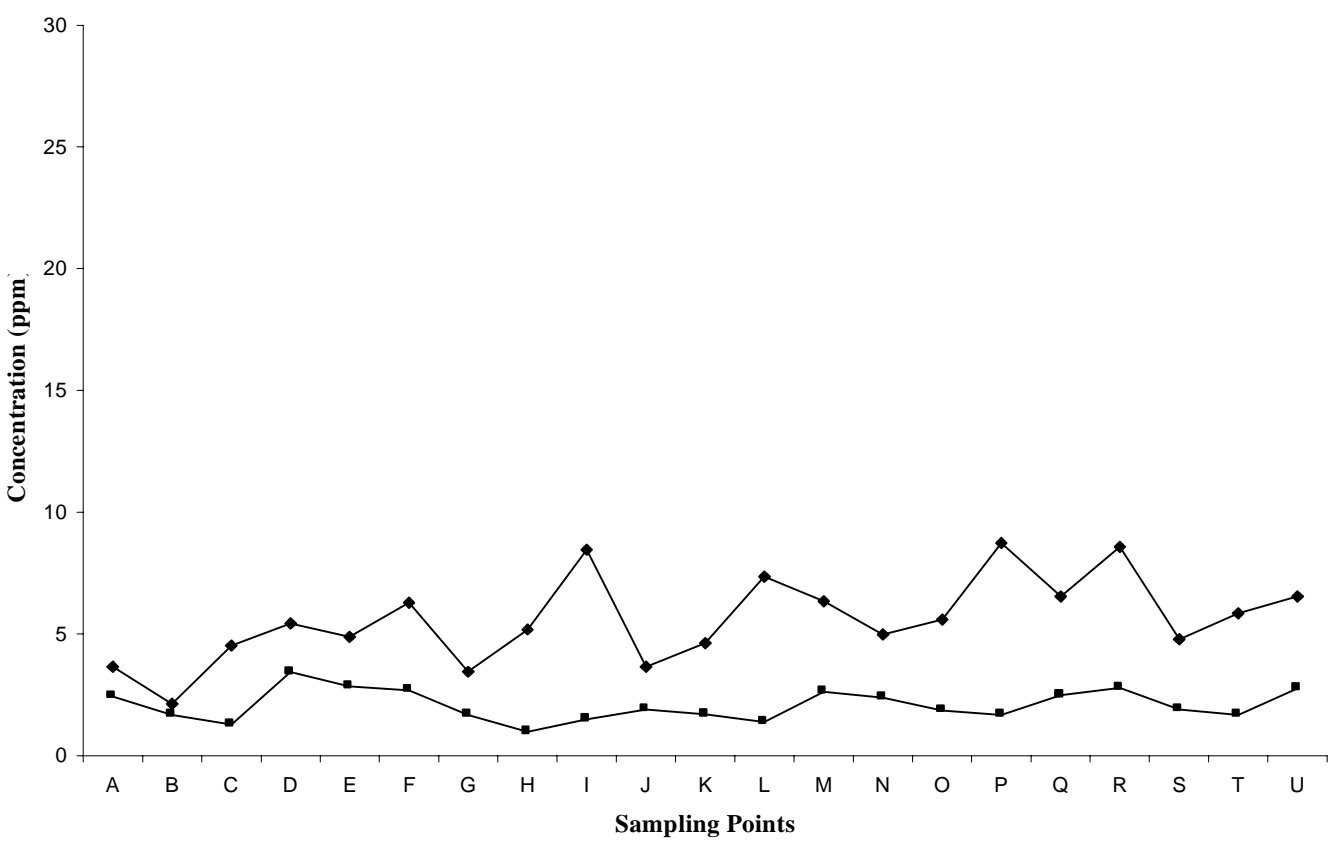

Fig. 2. Graph showing the concentration (p.p.m.) of $\mathrm{Cu}, \mathrm{Cr}$ and $\mathrm{Zn}$ in plantain

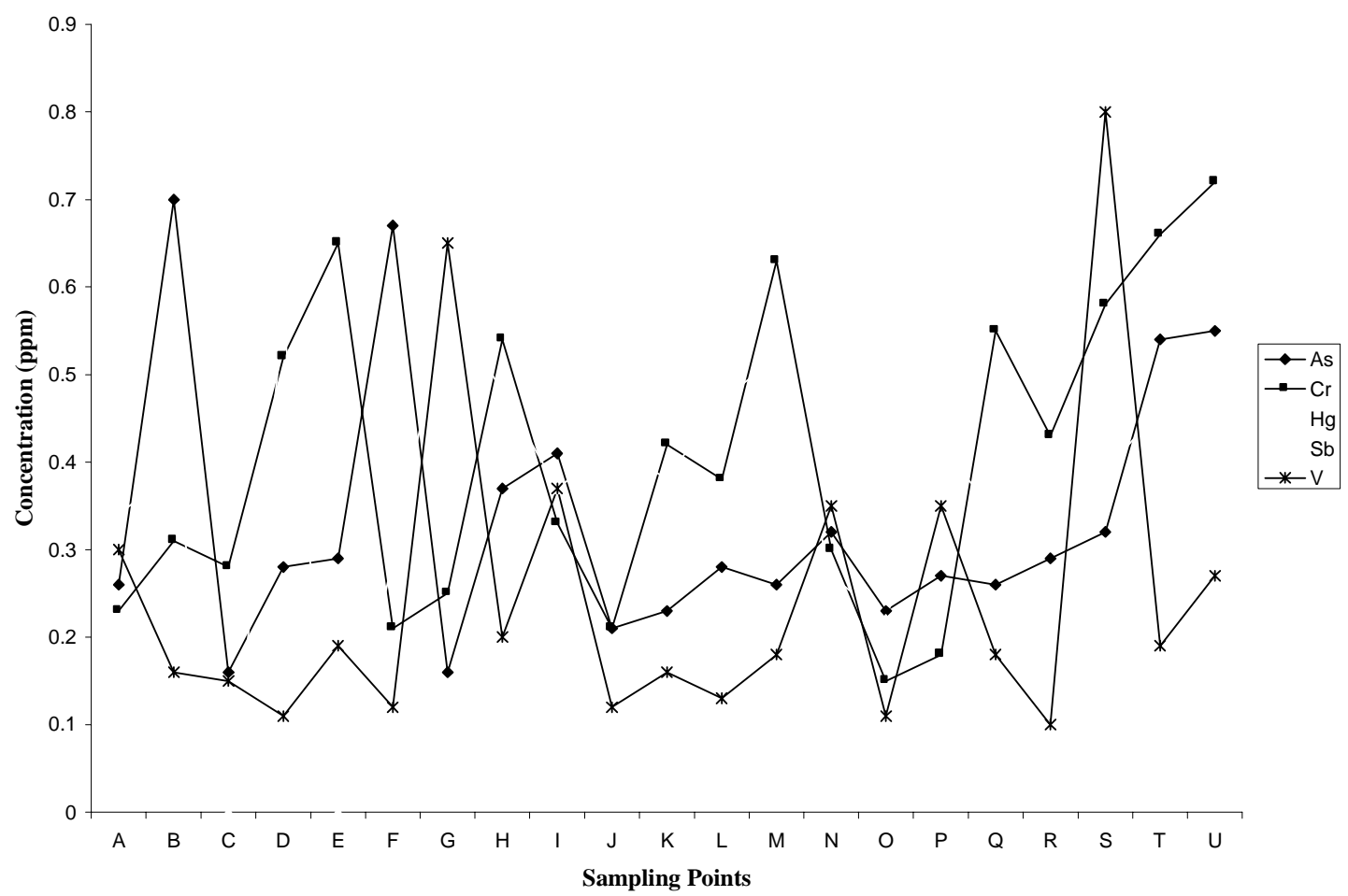




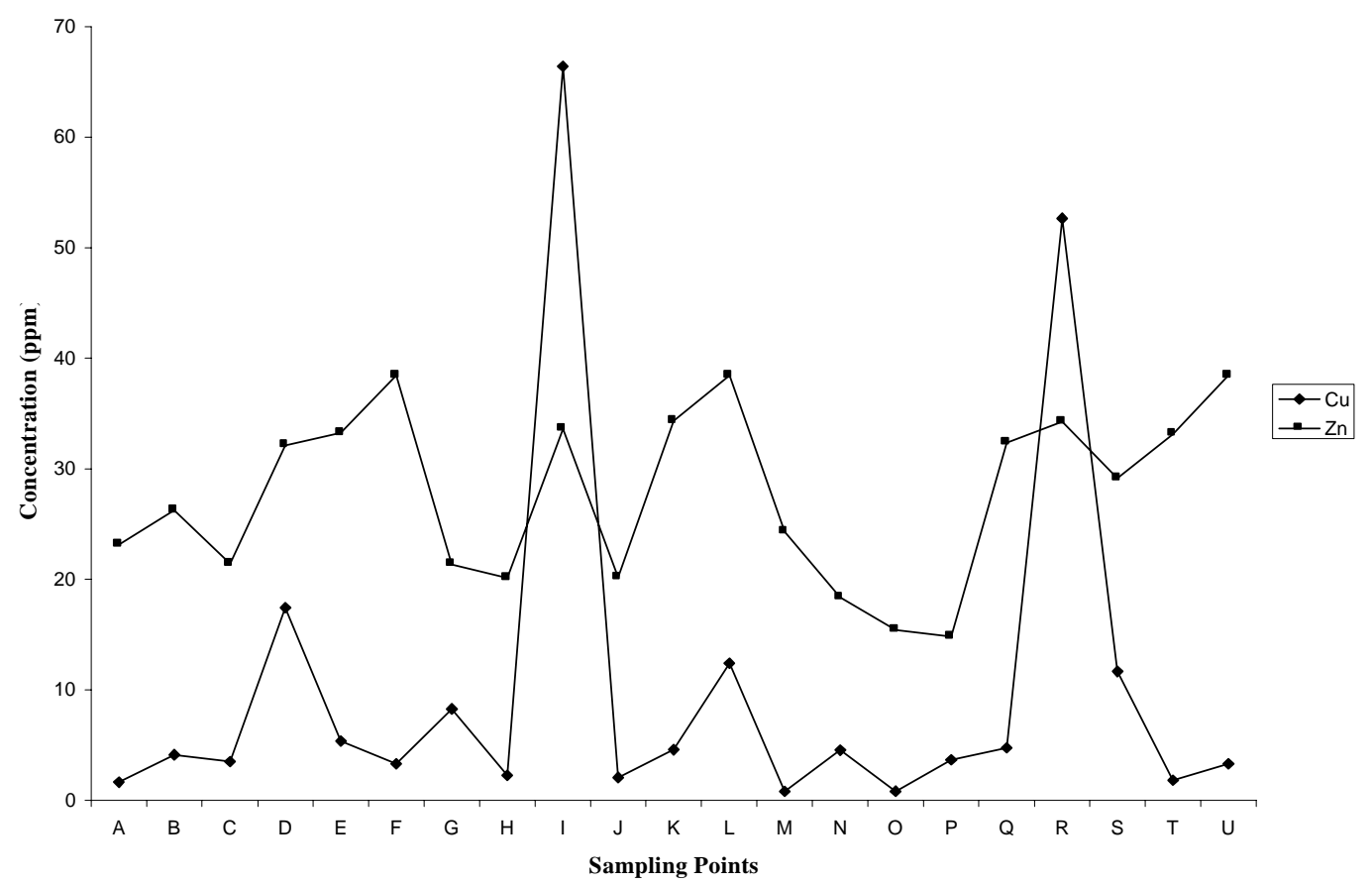

Fig. 3. Graph showing the concentration (p.p.m.) of $\mathrm{Cu}$ and $\mathrm{Zn}$ in cassava

A maximum intake of $10 \mu \mathrm{g} /$ day of $\mathrm{V}$ in cassava is the amount permitted by the Joint FAO/WHO Expert Committee on Food Additives. When this is compared to the maximum intake of $\mathrm{V}$ at Highway Quarters (Tables 1 and 2), it is found to be higher than the Joint FAO/WHO levels. Represen-tative concentrations of $\mathrm{Cu}, \mathrm{Cr}$ and $\mathrm{Zn}$ show higher values in plantain compared to FAO/WHO values (Table 2). Cu and Cr values for plantain from Tamso and Domeabra (Table 2) as well as $\mathrm{Cu}$ and $\mathrm{Zn}$ concen-trations for cassava (Table 1) at Agege and Domeabra have high values (Fig. 3). The concentrations of As, Hg, Sb, V, Cu, Zn and $\mathrm{Cr}$ for soil samples (Table 3) are within the permitted limits. Hg $(0.09 \mu \mathrm{g} / \mathrm{g})$ at Teberebie and V $(188.40 \mu \mathrm{g} / \mathrm{g})$ at UMaT, however, were above the permitted limits for soil samples.

TABLE 3

Toxic metal concentrations in soil samples. Table also shows communities where maximum and minimum values were recorded. Perm. Level = Permitted Level; High. Q. = Highway Quarters; Timber R. = Timber Road

\begin{tabular}{|c|c|c|c|c|c|c|}
\hline \multicolumn{2}{|c|}{ Toxic elements } & \multicolumn{2}{|l|}{ Sample Ort } & \multirow{2}{*}{$\begin{array}{l}\text { Values } \\
14.35 \mu \mathrm{g} / \mathrm{g}\end{array}$} & \multirow{2}{*}{$\begin{array}{l}\text { Conc./level } \\
\text { Soil conc. }\end{array}$} & \multirow{2}{*}{$\begin{array}{r}\text { Conc./source } \\
6 \mu \mathrm{g} / \mathrm{g}\end{array}$} \\
\hline As & $\max$ & Teberebie & (U) & & & \\
\hline & $\min$ & Domeabra & (P) & $0.62 \mu \mathrm{g} / \mathrm{g}$ & Perm. level & $20 \mu \mathrm{g} / \mathrm{g}$ \\
\hline \multirow[t]{2}{*}{$\mathrm{Hg}$} & $\max$ & Teberebie & (U) & $0.59 \mu \mathrm{g} / \mathrm{g}$ & Soil conc. & $0.09 \mu \mathrm{g} / \mathrm{g}$ \\
\hline & $\min$ & Jerusalem & (B) & $0.22 \mu \mathrm{g} / \mathrm{g}$ & Perm. level & $5 \mu \mathrm{g} / \mathrm{g}$ \\
\hline \multirow[t]{2}{*}{$\mathrm{Sb}$} & $\max$ & Teberebie & (U) & $2.98 \mu \mathrm{g} / \mathrm{g}$ & Soil conc. & $1 \mu \mathrm{g} / \mathrm{g}$ \\
\hline & $\min$ & High. Q. & (S) & $0.48 \mu \mathrm{g} / \mathrm{g}$ & Perm. level & $5 \mu \mathrm{g} / \mathrm{g}$ \\
\hline \multirow[t]{2}{*}{ V } & $\max$ & UMaT & (Q) & $188,40 \mu \mathrm{g} / \mathrm{g}$ & Soil conc. & $90 \mu \mathrm{g} / \mathrm{g}$ \\
\hline & $\min$ & Mile 8 1⁄2 & (I) & $121 \mu \mathrm{g} / \mathrm{g}$ & Perm. level & 90 ug/g \\
\hline \multirow[t]{2}{*}{$\mathrm{Cu}$} & $\max$ & Akafo & (R) & $53.46 \mu \mathrm{g} / \mathrm{g}$ & Soil conc. & $70 \mu \mathrm{g} / \mathrm{g}$ \\
\hline & $\min$ & Tamso & (D) & $1.85 \mu \mathrm{g} / \mathrm{g}$ & Perm. level & $100 \mu \mathrm{g} / \mathrm{g}$ \\
\hline \multirow[t]{2}{*}{$\mathrm{Zn}$} & $\max$ & High. Q. & (S) & $38.42 \mu \mathrm{g} / \mathrm{g}$ & Soil conc. & $90 \mu \mathrm{g} / \mathrm{g}$ \\
\hline & $\min$ & Timber R. & $(\mathrm{K})$ & $14.82 \mu \mathrm{g} / \mathrm{g}$ & Perm. level & $300 \mu \mathrm{g} / \mathrm{g}$ \\
\hline $\mathrm{Cr}$ & $\max$ & Teberebie & (U) & $42.36 \mu \mathrm{g} / \mathrm{g}$ & Soil conc. & $70 \mu \mathrm{g} / \mathrm{g}$ \\
\hline
\end{tabular}

West African Journal of Applied Ecology, vol. 14, 2008 

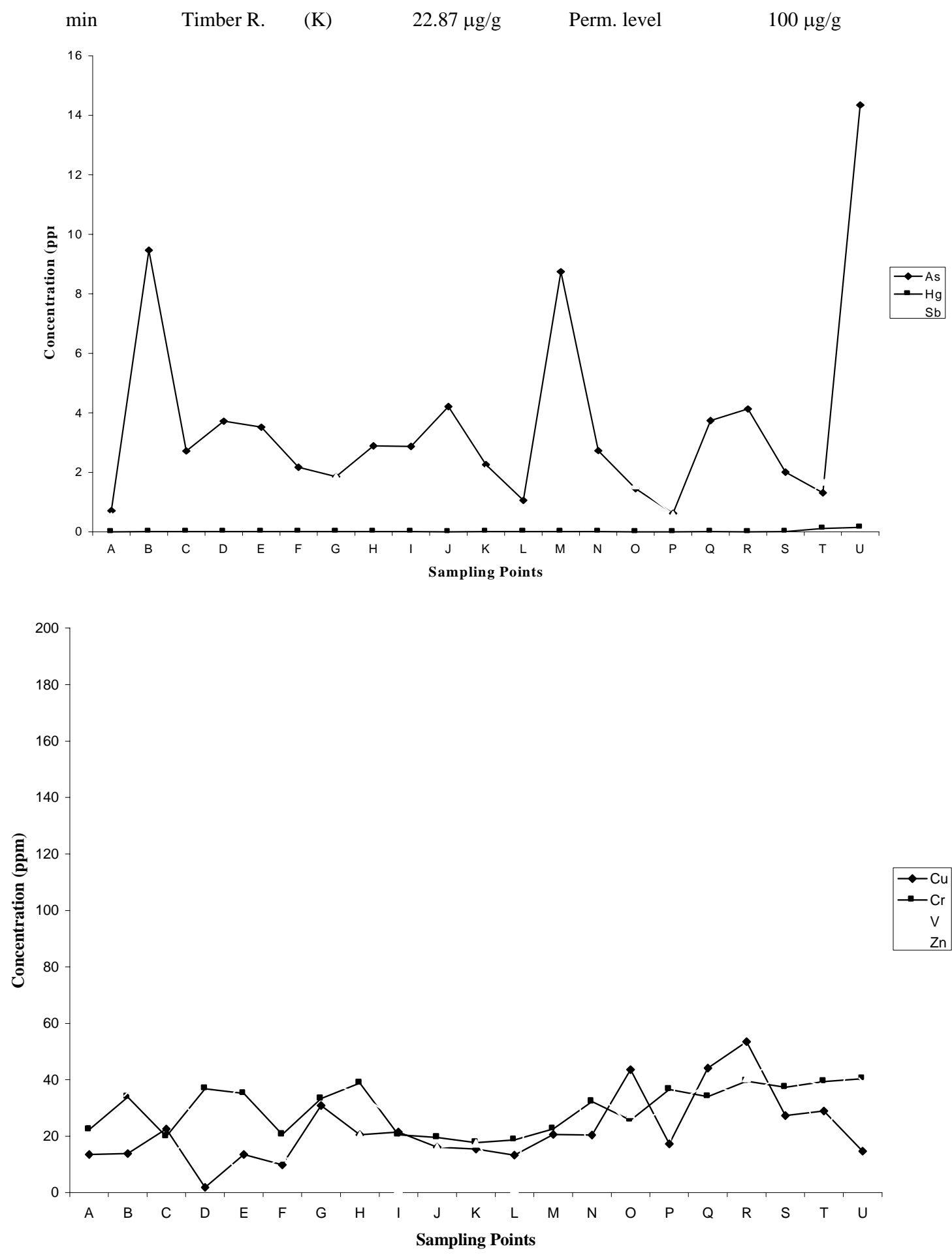

Fig. 4. Graph showing the concentration (p.p.m.) of $\mathrm{Cu}, \mathrm{Cr}, \mathrm{V}$ and $\mathrm{Zn}$ in soil

It is observed that the toxic element concentrations in the plantain and cassava relative to the permitted levels of the FAO/WHO are higher than the relative values for soil. It was, therefore, necessary to find the reason for this depletion in the soil. Generally, as a result of acid mine drainage, chemicals entering the water system, subsequently, enter the soil. The soil absorbs part of the chemicals which, subsequently, become part of the photosynthetic processes. It is, therefore, assumed that the concentra-tions of toxic metals in the cassava and plantain would reflect the concentrations in the soil samples. This is not the case. The high concentrations of elements in cassava and plantain did not reflect the values in the soil. Instead, the values in the soil samples were mostly lower than the permissible limits except $\mathrm{Hg}$ at Teberebie. 
To find out the contribution of the soil to the excess concentrations in the cassava and plantain, it was decided to go back to the field to collect reference soil samples. This time from uncultivated field, half kilometer away from the cassava and plantain field. Analysis obtained from the reference samples showed higher concentrations of soil. As $=25 \mu \mathrm{g} / \mathrm{g}, \mathrm{Hg}=5.5 \mu \mathrm{g} / \mathrm{g}, \mathrm{Sb}=7 \mu \mathrm{g} / \mathrm{g}, \mathrm{V}=90$ $\mu \mathrm{g} / \mathrm{g}, \mathrm{Cu}=110 \mu \mathrm{g} / \mathrm{g}, \mathrm{Zn}=305 \mu \mathrm{g} / \mathrm{g}, \mathrm{Cr}=105 \mu \mathrm{g} / \mathrm{g}$. This indicates clearly that cassava and plantain have depleted the concentrations of the elements in the soil on which the cassava and the plantain were cultivated. The source of the concentrations in the cassava and the plantain is, therefore, the soil. It also shows that the depleted toxic elements in the soil found itself in the cassava tubers and plantain fruits.

It also became necessary to find out why the concentrations in the plantain were more than that in the cassava. According to Fitzgerald et al. (1998) atmospheric mercury concentration has some influence on plant crop and its fruits. Atmospheric influences could possibly be the source of the high concentrations in the plantain. To follow this trace, the accuracy and precision of the analytical technique were assessed by simultaneous activation of the reference materials IAEA Soil 7 and IAEA-1547 peach leaves of the neutron activator. The activation leads to the calculation of the enrichment factor $(\mathrm{EF})$, which helps to distinguish between contribution from air pollution and that from a crustal component associated with wind blown soil particles.

The EF compares the concentration of individual elements of interest to the concentration of a conservative soil element, usually scandium (Sc) as standard. This is because Sc is not subject to contamination by anthropogenic sources. The result obtained showed that the enrichment factor for plantain is greater than that for cassava, suggesting that atmospheric deposition contributed to the increases of the toxic elements in plantain. This indicates atmospheric deposition and influences had taken place in commensuration with the researches of Ford (2001) and Frontasyeva et al. (2004).

Another problem was the fluctuating minimum consumption rate. The plantain and cassava consumption, based on data collected from inhabitants through questionnaire and personal observation, indicate minimum consumption of $800 \mathrm{~g}$ of plantain and cassava per day. Visits to some households gave a fairly good idea of the weight of fufu consumed in the afternoon and/or evening by an individual. The values range between $750 \mathrm{~g} /$ day to $800 \mathrm{~g} /$ day for adult. In making use of these figures it is important to note that members of the selected households also engage in the consumption of roasted plantain and kelewele during the course of the day.

Fufu was selected as preferred daily meal. The scenario where modeled estimates in some household indicated that fufu was consumed three times daily implying higher consumption rate was ignored. From this perspective the error margin associated with consumption rate of $800 \mathrm{~g}$ of plantain and cassava per day becomes trivial considering that the values between $750 \mathrm{~g} / \mathrm{day}$ and 800 g/day can be significantly higher in other communities. However, if a possible error margin of $8 \%$ should be considered and so calculate with the minimum value of $75 \mathrm{~g} / \mathrm{day}$, instead of the maximum $800 \mathrm{~g} /$ day, values much higher than the FAO/WHO values for cassava and plantain were obtained. It is also worth mentioning that Ghanaians consume cassava or plantain in cooked form and not the raw or uncooked form. It can be boiled, roasted or even fried. The elemental analysis performed was, however, carried out on the edible portions of raw cassava and plantain. It is possible, that cooking might reduce the elemental concentrations $(\mu \mathrm{g} / \mathrm{g})$ in cassava and plantain. The extent to which this is possible and viable cannot be ascertained yet by this research.

\section{Conclusion}

Using a daily maximum intake of $800 \mathrm{~g}$ of cassava and plantain the intake of zinc, arsenic, chromium, mercury, antimony, vanadium and copper in cassava and plantain are significantly above the daily maximum intake values set by the Joint FAO/WHO Expert Committee on Food Additives and the Agency for Toxic Substance and Disease Registry. The enrichment factor analysis for plantain is greater than that for cassava. Mercury is the element that is chiefly enriched 
in both cassava and plantain. The second predominant element enriched in cassava and plantain is zinc.

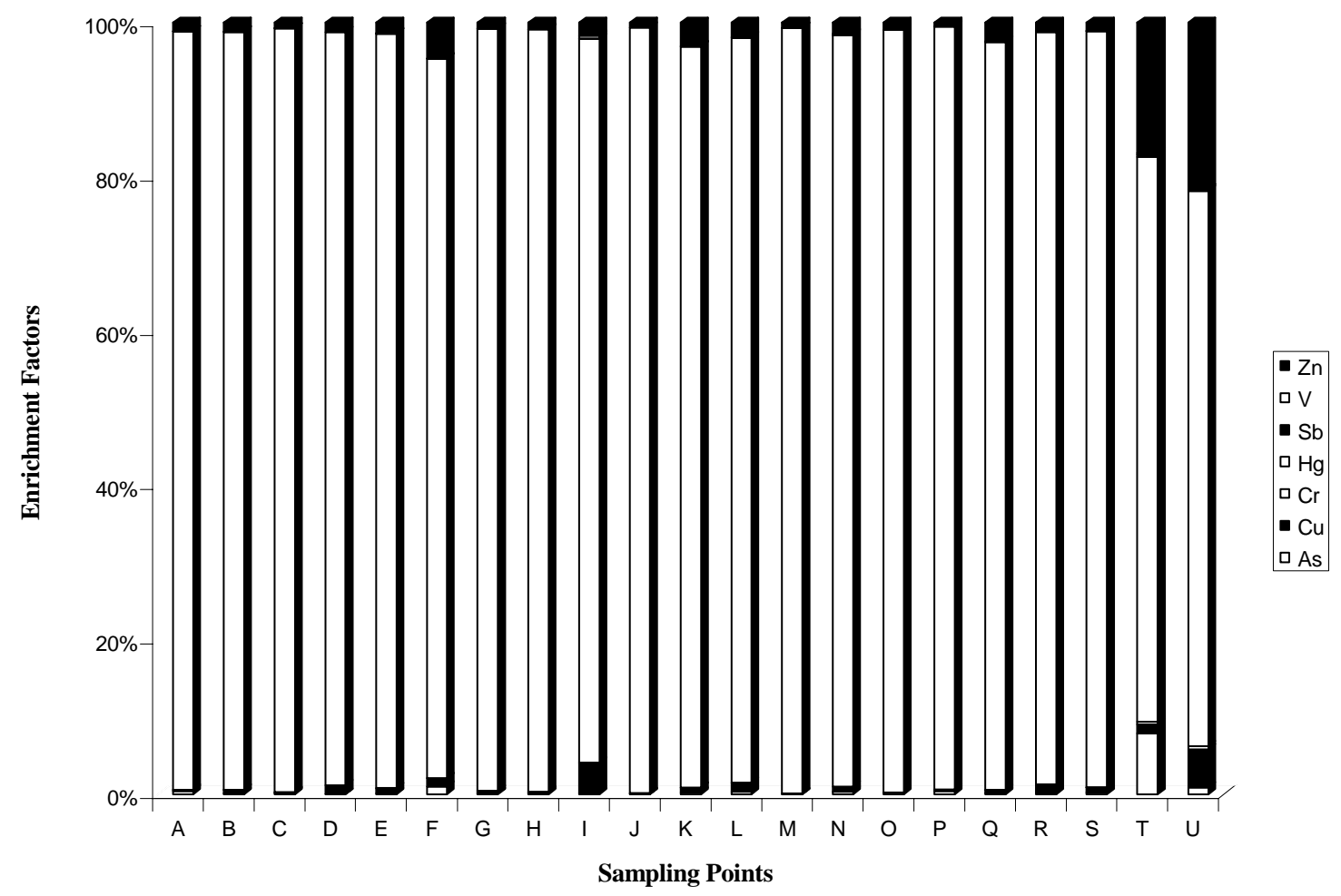

Fig. 5. Graph of enrichment factor for cassava against sampling points

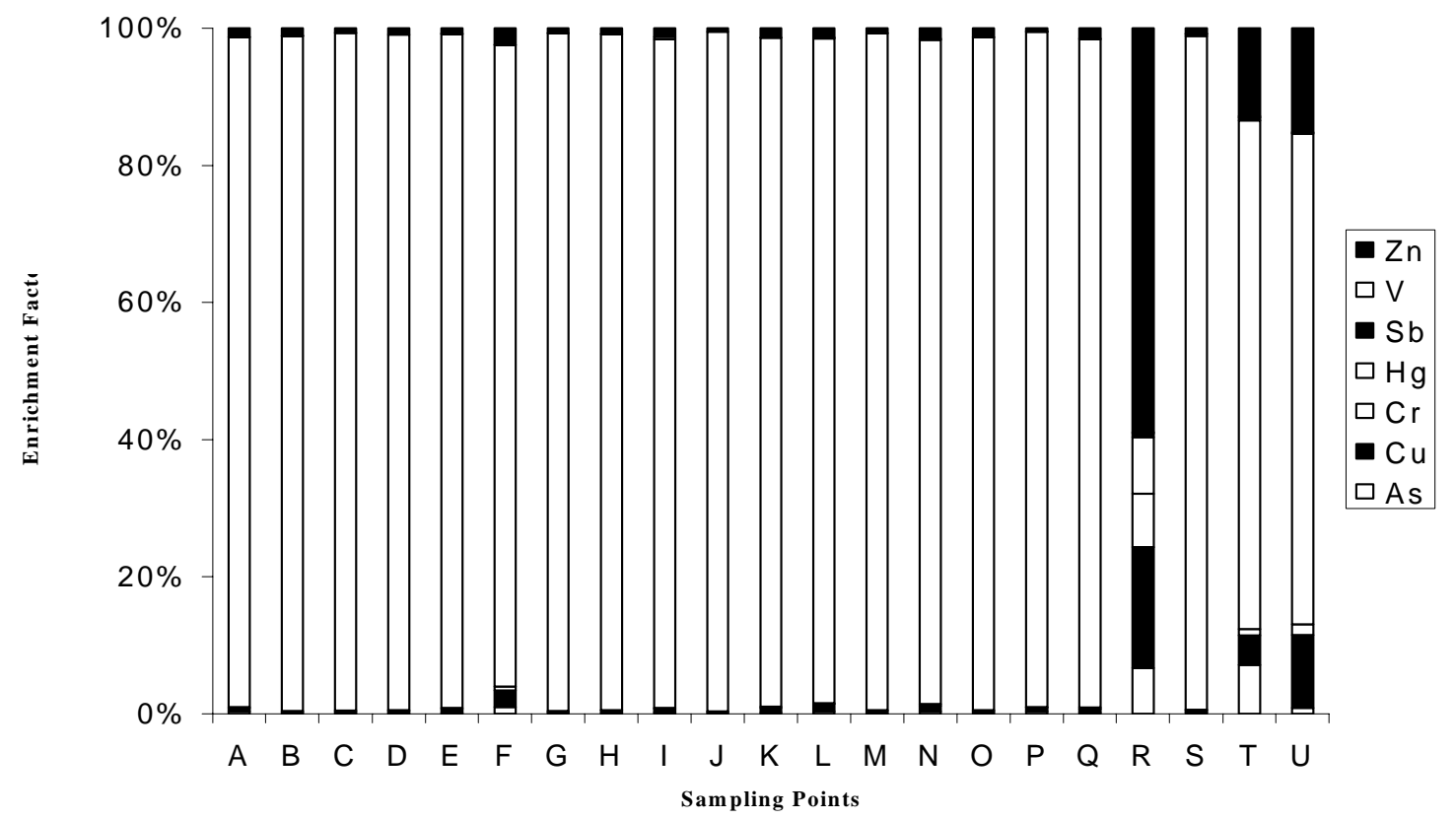

Fig .6. Graph of enrichment factor for plantain against sampling points

Soil concentrations in mercury and vanadium are above the normal concentra-tion levels. It can, thus, be concluded that the soils from the communities are polluted with mercury at Teberebie, and vanadium at UMaT. From Fig. 5 it can be deduced that of all the elements under investigation, the most enriched element in cassava was mercury. The enriched elements in cassava were in this order: mercury $>$ zinc $>$ arsenic $>$ copper $>$ chromium $>$ vanadium $>$ antimony. The most enriched 
element in plantain was mercury (Fig. 6). The enriched elements in plantain were in the order: mercury $>$ zinc $>$ copper $>$ arsenic $>$ chromium $>$ antimony $>$ vanadium. Arsenic, antimony, chromium, copper and zinc had permissible soil concentrations.

\section{Acknowledgement}

The authors are grateful to the management of Ghana Atomic Energy Commission for permitting the use of their research facility. Further the authors wish to thank Messrs Adomako, Quagrine, B. J. B. and Opata, all of the Ghana Atomic Energy Commission, for their contribution towards the collection and analysis of the data. They are also grateful to colleagues for helpful discussions.

\section{References}

Adimado A. A. and Baah D. A. (2002). Mercury in Human Blood, Urine, Hair and Fish from the Ankobra and Tano river basins in South-western Ghana. Bull. envir. Contam. Toxicol. 68: 339-346.

Agency for Toxic Substances and Disease Registry (1992). Toxicological Profile for Antimony. U.S. Department of Health and Human Services, New York, NY.

Banermann W., Potin-Gautier M., Amouroux D., Tellier S., Rambaud A., Babut M., Adimado A. and Beinhoff C. (2003). Mercury and arsenic in the gold mining regions in the Ankobra river basin in Ghana. J. Phys. IV 107: 197110.

Berner R. A. (1970). Sedimentary pyrite oxidation an update. Am.J. Sci. 268: 1-10.

Bonzongo J. C., Donkor A. K. and Nartey V. K. (2003). Environmental impacts of mercury related to artisanal gold mining in Ghana. J. Phys. IV France 107: 217-220.

Bowen H. J. M. (1979). Environmental Chemistry of the Elements. Academic Press, London.

Cleary D. and Thornton I. (1994). The environmental impact of gold mining in the Brazilan Amazon. Envir. Sci. Technol. 1: 17-25.

Encarta (2002). Encarta Encyclopedia: Mining. MSN Learning and Research.

Fitzgerald W. F., Engstr D. R., Mason R. P. and Narer E. D. (1998). The case for atmospheric Mercury contamination in remote areas. Envir. Sci. Technol. 32 (1): 1-7.

Ford J. (2001). Heavy Metals in Mosses and Soils on Six Transects Along the Red Dog Mine Haul Road, Alaska. NPS/ AR/ NRTR 38: 12-14.

Fortescue J. A. C. (1992) Landscape Geochemistry: Retrospect and Prospect 1990: Appl. Geochem.7: 1-54.

Frontasyeva M. V., Smirnov L. I., Steinness E., Lyapunov S. M. and Cherchintesv V. D. (2004). A Heavy Metal Atmospheric Deposition Study in the South Ural Mountains. J. Radioanal. Nucl. Chem. 259 (1): 19-26.

Giblin A. E. (1988) Pyrite formation in marshes during early diagnoses. Biotechnol. Bioengng 9: 471-481.

Hastings D. A. (1983). On the tetonics and metallogenesis of Ghana. A model based on a new synthesis of geological and geographical data. Ghana Geological Survey Department, Accra.

Minerals Commission (1996). Environmental Effects of Small and Large Scale Mining in Ghana. Minerals Commission, Accra

Steinnes E. and Berg T. (1998). Significance of Long-Range Atmospheric Transport for Heavy Metal and Radionuclide Contamination of Terrestrial Environment. Am. Mineral. 80: 429-443.

Taylor R. S. and Mc Lennan S. M. (1992). The Continental Crust:its composition and evolution. Blackwell Scientific Publisher, Oxford-London-Edinburgh. 312 pp.

Tsikata F. S. (1887). The vicissitude of mineral policy in Ghana. Resour. Pol. 23 (1-2): 9-14.

WHO (1996). Trace Elements in Human Nutrition and Health. World Health Organization, Geneva. 